Gut, 1972, 13, 128-137

\title{
Plasma protein turnover (albumin, transferrin, IgG, IgM) in Ménétrier's disease (giant hypertrophic gastritis): Evidence of non-selective protein loss ${ }^{1}$
}

\author{
STIG JARNUM AND KURT BIRGER JENSEN
}

From the Medical Department P, Division of Gastroenterology, Rigshospitalet, Copenhagen, Denmark

SUMMARY Ten cases of Ménétrier's disease ('giant hypertrophic gastritis') have been studied with radioiodine-labelled albumin (all 10 cases), IgG (eight cases), transferrin (two cases), and IgM (six cases). Abnormal gastric loss of plasma protein was present in all cases as demonstrated by ${ }^{59} \mathrm{Fe}$-iron dextran (eight cases), ${ }^{51} \mathrm{Cr}$-albumin (one case), and ${ }^{131}$ I-polyvinylpyrrolidone (one case).

None of the patients had more distal gastrointestinal lesions. The synthetic rate of the proteins studied was normal or slightly elevated.

The fractional catabolic rate of the proteins was increased. The increase above the normal mean was similar for albumin, transferrin, and IgG. Since the molecular weight of IgG is more than twice that of albumin and transferrin, it is concluded that the protein loss in Ménétrier's disease is nonselective in the sense that it affects a similar fraction of the intravascular masses of all plasma proteins. IgM catabolism was strongly accelerated. Simultaneous studies with ${ }^{59} \mathrm{Fe}$-iron dextran, radioiodinelabelled albumin or IgG showed that IgM hypercatabolism could only partly be due to abnormal gastric protein loss, since IgM catabolism was significantly more raised than that of albumin and IgG. Faecal radioiodine excretion was normal in most patients after the injection of radioiodinelabelled proteins. It confirms a previous observation that increased gastrointestinal ${ }^{59} \mathrm{Fe}$ clearance after injection of ${ }^{59} \mathrm{Fe}$-iron dextran associated with normal faecal radioiodine excretion after the injection of radioiodine-labelled proteins permits of a diagnosis of protein loss in the stomach.

In 1888 Ménétrier described a peculiar lesion of the stomach consisting of widespread hypertrophy of the mucosal folds (polyadénomes en nappe'). He was credited eponymously for his observation (Ménétrier's disease). Some 200 cases with a similar lesion have been published in this century. A different term has been used in several instances, eg, giant hypertrophic gastritis, giant mucosal rugae, proteinlosing gastropathy, a fact which suggests that the pathoanatomical lesion may not represent a nosological unity. The course of the disease is most often benign. In rare cases carcinoma develops. Severe haemorrhage or oedema due to hypoproteinaemia occasionally requires partial or total gastrectomy.

Hypoproteinaemia is frequent, and occurs in about $70 \%$ of the cases (Jarnum, 1963). Serum albumin is depressed, but even the concentration of $\beta$ - and $\gamma$-globulins may be lowered. Using ${ }^{131}$ I-albumin

'The work was supported by grants from P. Carl Petersens Fond and Christian d. X. Fond.

Received for publication 25 November 1971.
Citrin, Sterling and Halsted (1957) showed that abnormal gastric plasma protein loss was responsible for the hypoproteinaemia. They were able to quantitate the albumin loss directly by analyses of gastric secretions aspirated continuously over a prolonged period ( 24 hours). However, the method is laborious, unpleasant for the patient, and probably inferior to more recent methods, which apply isotopelabelled macromolecular compounds in which the isotope, as opposed to ${ }^{131} \mathrm{I}$ in ${ }^{131} \mathrm{I}$-albumin, is not absorbed from the lumen of the gastrointestinal tract. ${ }^{67} \mathrm{Cu}$-labelled coeruloplasmin fulfils this condition (Waldmann, Morell, Wochner, Strober, and Sternlieb, 1967) but the tracer is expensive. ${ }^{51}$ Cr-albumin (Waldmann, 1966) and ${ }^{59} \mathrm{Fe}$-iron dextran (Jarnum, Westergaard, Yssing, and Jensen, 1968) also seem to be valid test substances for the detection and quantitation of gastrointestinal protein loss. However, no tracer substance can accurately reflect the loss of some 100 plasma proteins of widely differing molecular size unless the 
protein loss is a 'bulk loss', which evenly comprises all plasma proteins.

In the present report 10 patients with Ménétrier's disease were studied. ${ }^{59} \mathrm{Fe}$-iron dextran, ${ }^{131} \mathrm{I}$-albumin (MW (molecular weight) about 68000), ${ }^{131}$ I-transferrin (MW about 70000), ${ }^{125} \mathrm{~J}-\mathrm{IgG}$ (MW about 160000 ), and ${ }^{125}$ I-IgM (MW about 920000) were used to assess whether a bulk loss took place.

\section{Methods}

SERUM PROTEIN DETERMINATION

The serum concentration of albumin, IgG, and IgM was determined by an immunochemical method (Mancini, Carbonara, and Heremans, 1965).

GASTROINTESTINAL PROTEIN LOSS

This was assessed by means of ${ }^{59} \mathrm{Fe}$-labelled iron dextran obtained from Pharmacia, Copenhagen, and manufactured at the Radiochemical Centre, Amersham, England (Jarnum et al, 1968).

\section{TURNOVER STUDIES}

Metabolically homogeneous ${ }^{131}$ I-labelled human albumin was obtained from Institutt for Atomenergi, Kjeller, Norway (code MISN).

Immunoglobulin-G was prepared from normal human serum by means of DEAE cellulose chromatography (Peterson and Sober, 1960).

\section{ISOLATION AND LABELLING OF IGM}

IgM was isolated from normal human serum by means of Sepharose 4B gel filtration (Jensen, 1969, 1970).

\section{RADIOIODINE LABELLING OF}

IMMUNOGLOBULIN S

IgG and IgM were labelled with ${ }^{131}$ I according to the ICI method of McFarlane (1958). On an average the labelled preparations contained one atom of iodine per molecule. More than $99.5 \%$ of the radioactivity was precipitable by trichloroacetic acid.

\section{PROCEDURE}

Thyroid uptake of radioiodide was prevented by daily oral administration of $50 \mathrm{mg}$ potassium iodide from the day before and during the turnover study. Studies with ${ }^{59} \mathrm{Fe}-,{ }^{131} \mathrm{I}$-, and ${ }^{125} \mathrm{I}$-labelled preparations were performed simultaneously. Serum protein determinations were performed each day and used to correct the serum radioactivity for minor fluctuations in protein concentration. The patients were admitted to the ward during the study. None was confined to bed. Daily control of body weight and temperature and regular estimation of haemoglobin and serum proteins ensured that the patients were in a metabolically steady state condition.

Weighed amounts of the labelled preparations were administered intravenously. About $0.04 \mu \mathrm{Ci}$ of ${ }^{59} \mathrm{Fe}, 0.4 \mu \mathrm{Ci}$ of ${ }^{131} \mathrm{I}$, and $0 \cdot 15 \mu \mathrm{Ci}$ of ${ }^{125} \mathrm{I}$ per $\mathrm{kg}$ were given to the patients. Radioactivity in serum was recorded 10 minutes after the injection and subsequently at daily intervals. In addition ${ }^{59} \mathrm{Fe}$ and 131I activity was recorded by a whole body counter (Jarnum et cil, 1968), which permitted the investigations to conclude within eight to 12 days.

Stools were collected until they became red after the oral administration of $1 \mathrm{~g}$ of carmin 96 hours after the injection. Urine was collected in 24-hour specimens during the studies. Radioactivity in serum and urine was measured in $3 \mathrm{ml}$ samples by means of a three-channel gammaspectrometer (Auto-Gammaspectrometer, Packard). Stool activity was measured in 24-hour samples in a large volume counter (Armac, Packard).

CALCULATION OF THE METABOLIC DATA The faecal excretion of ${ }^{59} \mathrm{Fe}$ was expressed as a percentage of the injected dose, and the gastrointestinal clearance of ${ }^{59} \mathrm{Fe}$-labelled iron dextran was calculated as the percentage of intravascular ${ }^{50} \mathrm{Fe}$ excreted in the stools per day (Jarnum et al, 1968).

Albumin and IgG turnover was calculated by mathematical analysis of the multiexponential curve formed when plasma radioactivity was plotted against time in a semilogarithmic system (Nosslin, 1966). Synthesis was deduced from the calculated catabolic rate, which is only permissible if a steady state is prevailing throughout the study. This was actually the case as judged from the patients' body weights, haemoglobin, and serum protein values.

The turnover of labelled IgM was calculated from plots of serum activity and retained activity (as determined by whole body counting) against time in a semilogarithmic system. According to Berson, Yalow, Schreiber, and Post (1953), the intravascular fraction of the labelled protein is equal to the ratio between the intercepts at zero time of the parallel final slopes of the serum and whole body curves, and the fractional catabolic rate is the slope constant divided by this ratio. Plasma volumes were determined by simple isotope dilution. The fractional catabolic rate is the percentage of the intravascular mass of protein degraded per day. The intravascular fraction denotes the fraction of the total body mass localized intravascularly. The intravascular mass equals plasma volume $\times$ serum concentration. The synthesis rate denotes the absolute amount of protein which is synthesized (or degraded) per day. It equals intravascular mass $\times$ fractional catabolic rate. 
Faecal ${ }^{131}$ I excretion during the first four or five days of the study was calculated as a percentage of the injected dose. All patients were studied simultaneously, or separated by an interval of one or two weeks, with ${ }^{59} \mathrm{Fe}$-iron dextran (for assessment of gastrointestinal protein loss) and radioiodine ${ }^{\left({ }^{125}\right.} \mathrm{I}$ or 181I) labelled albumin and IgG and IgM.

\section{GASTRIC PROTEIN CLEARANCE}

In five patients gastric aspiration was continuous over one to five hours from one to nine days after the injection of labelled proteins. The amount of protein-bound radioactivity per minute was related to the simultaneous plasma concentration of labelled protein, and the gastric 'clearance' of labelled protein was calculated. Gastric protein clearance was related to total metabolic clearance which was obtained from the product of plasma volume $(\mathrm{ml})$ and the fractional catabolic rate (percentage per day).

In one patient (case 8) clearance studies of gastric IgG and albumin clearance were done following hexamethonium-induced 'vagotomy'. In a subsequent study of the same patient during an augmented histamine test and after an additional injection of ${ }^{125} \mathrm{I}$ albumin, the proteolysis of the gastric juice was reduced by instillation of phosphate buffer (sodium phosphate, ionic strength $0 \cdot 2, p \mathrm{H} 7 \cdot 2$ ) every five to 10 minutes.

\section{Case Material}

The diagnosis, Ménétrier's disease, was considered to comprise 'giant rugae' as well as giant rugae plus gastric polyps. It was based on radiography, the macroscopic appearance of the gastric mucosa on gastroscopy or laparotomy, and the microscopic picture of a biopsy or a surgical specimen. Ten patients were studied, three females and seven males, with an age range from 29 to 62 years. Laboratory and clinical findings are summarized in Tables I and II. Three patients (cases 8, 9, 10) suffered from additional diseases which are known to influence plasma protein turnover (sarcoidosis in prednisone treatment (case 8), nephrotic syndrome (case 9), and pulmonary carcinoma (case 10)).

The disease turned out to be transitory in the three females. Gastrointestinal plasma protein loss was estimated by means of ${ }^{59} \mathrm{Fe}$-iron dextran in eight patients (Jarnum et al, 1968), ${ }^{51} \mathrm{Cr}$-albumin in one patient (Waldmann, 1966), and 131I-polyvinylpyrrolidone in one patient (Gordon, 1959). Albumin turnover was studied in 10 patients. Case 4 was studied twice, before and after gastric resection. ${ }^{125} \mathrm{I}$-IgG turnover was studied in eight patients, and ${ }^{131} \mathrm{I}-\mathrm{IgM}$ turnover in six patients (cases $1,3,5,6,9$, 10).

For comparison transferrin turnover determined in two patients (cases 7 and 9) has been included. The results have been published elsewhere (Jensen, Bro-Jørgensen, Jarnum, Olesen, and Yssing, 1968).

Control studies were carried out in normal persons or patients with disorders without known influence on serum protein turnover.

\section{Results}

ABNORMAL PLASMA PROTEIN LOSS

Increased faecal ${ }^{59} \mathrm{Fe}$ excretion and clearance was present in all patients studied (Table III). In patient no. 4 gastrointestinal plasma protein loss was demonstrated as increased faecal ${ }^{131} \mathrm{I}$ excretion after

\begin{tabular}{|c|c|c|c|c|c|c|c|c|}
\hline \multicolumn{3}{|c|}{$\begin{array}{c}\text { Case No. Sex and Age } \\
\text { (years) }\end{array}$} & \multirow{2}{*}{$\begin{array}{l}\text { Height } \\
(\mathrm{cm})\end{array}$} & \multirow{2}{*}{$\begin{array}{l}\begin{array}{l}\text { Weight } \\
(\mathrm{kg})\end{array} \\
46\end{array}$} & \multirow{2}{*}{$\begin{array}{l}\text { Associated Disease } \\
\text { Ventricular septal defect } \\
\text { Multiple skeletal malformations }\end{array}$} & \multicolumn{2}{|c|}{$\begin{array}{ll}\text { Haemoglobin } & \text { Blood in } \\
(\mathrm{g} / \mathrm{l}) & \text { Stools } \\
& \text { (benzidine) }\end{array}$} & \multirow{2}{*}{$\begin{array}{l}\text { Peak Acid Output (m-equiv/l } \mathrm{H}^{+} \\
\text {per hour (augmented histamine } \\
\text { or pentagastrine) }\end{array}$} \\
\hline 1 & $\mathbf{M}$ & 31 & & & & 81 & +++ & \\
\hline 2 & $\mathbf{M}$ & 41 & 181 & 88 & & 123 & 0 & $22 \cdot 0$ \\
\hline 3 & $\mathbf{M}$ & 57 & 171 & 59 & $\begin{array}{l}\text { Prostatic hypertrophy } \\
\text { Subclavian artery stenosis }\end{array}$ & 103 & $++t$ & $17 \cdot 0$ \\
\hline 4 & $\mathbf{M}$ & 62 & 169 & 63 & Diabetes & 147 & 0 & \\
\hline \multicolumn{9}{|c|}{ Transitory Ménétrier's Disease } \\
\hline 5 & $\mathrm{~F}$ & 29 & 156 & 56 & & 119 & $\mathbf{0}$ & $9 \cdot 8$ \\
\hline 6 & $\mathbf{F}$ & 35 & 151 & 45 & & 146 & $\mathbf{0}$ & $17 \cdot 2$ \\
\hline 7 & $\mathbf{F}$ & 52 & 157 & 57 & & 124 & 0 & $3 \cdot 2$ \\
\hline \multicolumn{9}{|c|}{ Cases with Associated Diseases Affecting Plasma Protein Turnover } \\
\hline 8 & $\mathbf{M}$ & 32 & 174 & 66 & $\begin{array}{l}\text { Sarcoidosis in prednisone } \\
\text { treatment }\end{array}$ & 135 & + & $3 \cdot 2$ \\
\hline 9 & $\mathbf{M}$ & 56 & 175 & 79 & $\begin{array}{l}\text { Nephrotic syndrome, coronary } \\
\text { sclerosis }\end{array}$ & 142 & $\mathbf{0}$ & $38 \cdot 0$ \\
\hline 10 & $\mathbf{M}$ & 61 & 170 & 83 & $\begin{array}{l}\text { Anaplastic pulmonary } \\
\text { carcinoma }\end{array}$ & 115 & $++t$ & 0 \\
\hline
\end{tabular}

Table I Ten cases of Ménétrier's disease 


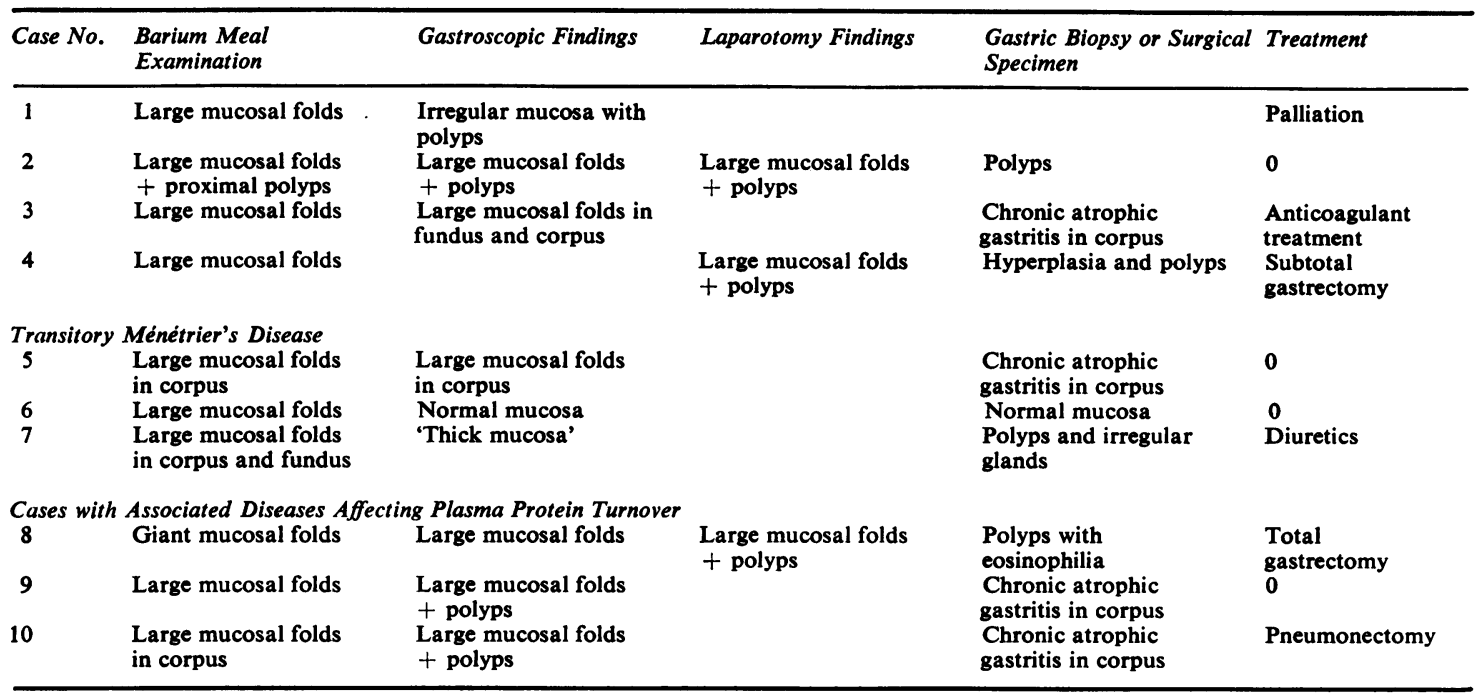

Table II Ten cases of Ménétrier's disease

\begin{tabular}{|c|c|c|c|c|c|c|c|}
\hline Case No. & $\begin{array}{l}\text { Serum Albumin } \\
(g / I)(34-51)\end{array}$ & $\begin{array}{l}\text { Fractional } \\
\text { Catabolic Rate } \\
\text { (\% per day) } \\
(7 \cdot 1-10 \cdot 3)\end{array}$ & $\begin{array}{l}\text { Distribution } \\
\text { Ratio Intra- } \\
\text { vascularMass as } \\
\% \text { of Total } \\
\text { Mass (37-52) }\end{array}$ & $\begin{array}{l}\text { Synthesis Rate } \\
(\mathrm{g} / 175 \mathrm{~cm} / \mathrm{d}) \\
(7 \cdot 3-14 \cdot 4)\end{array}$ & $\begin{array}{l}\text { Faecal Radio- } \\
\text { iodine Excretion } \\
(\% \text { of injected } \\
\text { dose in } 4-5 \text { days) } \\
(<0.40 \%)\end{array}$ & $\begin{array}{l}\text { Faecal }{ }^{59} \mathrm{Fe} \\
\text { Excretion after } \\
\text { Intravenous Injection } \\
\text { of }{ }^{\circ \%} \text { Fe-iron dextran } \\
(\% \text { of injected dose } \\
\text { in } 4-5 \text { days })(<0.8 \%)\end{array}$ & $\begin{array}{l}\text { Gastrointestinal } \\
6 \% \text { Fe-clearance } \\
(\% \text { of intra- } \\
\text { vascular pool } \\
\text { per day) } \\
(<0.8 \%)\end{array}$ \\
\hline $\begin{array}{l}1 \\
2 \\
3 \\
4 a \\
4 b^{1}\end{array}$ & $\begin{array}{l}29 \cdot 3 \\
41 \cdot 3 \\
27 \cdot 2 \\
26 \cdot 1 \\
37 \cdot 8\end{array}$ & $\begin{array}{r}16 \cdot 2 \\
13 \cdot 3 \\
14 \cdot 3 \\
13 \cdot 4 \\
8 \cdot 0\end{array}$ & $\begin{array}{l}50 \cdot 2 \\
61 \cdot 2 \\
42 \cdot 0 \\
44 \cdot 0 \\
33 \cdot 6\end{array}$ & $\begin{array}{l}14 \cdot 8 \\
19 \cdot 5 \\
11 \cdot 0 \\
10 \cdot 1 \\
10 \cdot 0\end{array}$ & $\begin{array}{l}\text { Unknown } \\
0.13 \\
0.51 \\
0.47 \\
0.14\end{array}$ & $\begin{array}{c}4 \cdot 3 \\
3 \cdot 9 \\
6 \cdot 8 \\
(4 \cdot 8)^{2} \\
(1 \cdot 0)^{2}\end{array}$ & $\begin{array}{r}7 \cdot 5 \\
4 \cdot 4 \\
10 \cdot 9\end{array}$ \\
\hline $\begin{array}{l}5 \\
6 \\
7\end{array}$ & $\begin{array}{l}23 \cdot 3 \\
29 \cdot 8 \\
23 \cdot 8\end{array}$ & $\begin{array}{l}17 \cdot 6 \\
13 \cdot 9 \\
24 \cdot 5\end{array}$ & $\begin{array}{l}47 \cdot 3 \\
59 \cdot 4 \\
56 \cdot 2\end{array}$ & $\begin{array}{r}11 \cdot 3 \\
8 \cdot 5 \\
16 \cdot 4\end{array}$ & $\begin{array}{l}0.29 \\
0.41 \\
0.30\end{array}$ & $\begin{array}{r}11 \cdot 0 \\
6 \cdot 7 \\
8 \cdot 7\end{array}$ & $\begin{array}{l}15 \cdot 9 \\
10 \cdot 0 \\
13 \cdot 4\end{array}$ \\
\hline $\begin{array}{r}8 \\
9 \\
10\end{array}$ & $\begin{array}{l}27 \cdot 8 \\
26 \cdot 1 \\
27 \cdot 4\end{array}$ & $\begin{array}{l}23 \cdot 4 \\
23 \cdot 5^{4}(18 \cdot 2) \\
16 \cdot 0\end{array}$ & $\begin{array}{l}60 \cdot 7 \\
51 \cdot 7 \\
56 \cdot 4\end{array}$ & $\begin{array}{l}21 \cdot 5 \\
20 \cdot 9 \\
16 \cdot 7\end{array}$ & $\begin{array}{l}0.25 \\
0.19 \\
0.53\end{array}$ & $\begin{array}{c}(7 \cdot 5)^{3} \\
>3 \cdot 4 \\
7 \cdot 2\end{array}$ & $\begin{array}{l}(11 \cdot 7)^{8} \\
>5 \cdot 3 \\
8 \cdot 3\end{array}$ \\
\hline
\end{tabular}

Table III Albumin turnover and gastric protein loss $\left({ }^{59} \mathrm{Fe}\right.$-iron dextran) in Ménétrier's disease

${ }^{1}$ After subtotal gastrectomy.

${ }^{2}$ Faecal ${ }^{181}$ I excretion (percentage of injected dose) following intravenous injection of ${ }^{131}$ I-polyvinylpyrrolidone ( ${ }^{131}$ I-PVP). Normal value: $<1 \%$.

${ }^{3} \mathrm{Faecal}{ }^{51} \mathrm{Cr}$-excretion and clearance following intravenous injection of ${ }^{51} \mathrm{Cr}$-albumin. Normal value for both: $<1 \%$

${ }^{4}$ Corrected for proteinuria. Normal range is given in parentheses.

the injection of ${ }^{131} \mathrm{I}$-polyvinylpyrrolidone and in case 8 as increased ${ }^{51} \mathrm{Cr}$ excretion after ${ }^{51} \mathrm{Cr}$-albumin. Thus an abnormal protein loss occurred in all 10 patients.

\section{ALBUMIN}

Serum albumin levels were lowered in all patients except patient no. 2 (Table III). He was also the patient who presented one of the lowest gastrointestinal losses as judged from faecal ${ }^{59} \mathrm{Fe}$ clearance (Table III). One patient (case 4) attained a normal serum albumin level following gastric resection.

Hypoalbuminaemia was due to accelerated fractional catabolism, which was present in all patients. There was a trend towards a hyperbolic relation between serum albumin and the fractional catabolic rate(Fig. 1). Gastrointestinal ${ }^{59} \mathrm{Fe}$ clearance seemed to be positively related to the fractional catabolic rate of albumin (Fig. 2). However, the correlation was not statistically significant $(0 \cdot 10>$ $P>0.05$ ). Albumin synthesis was elevated in six patients (from 14.8 to $21.5 \mathrm{~g}$ per $175 \mathrm{~cm}$ per day) and normal in the remaining four. Because of varying degrees of oedema and malnutrition, the synthetic rate is related to body height (recalculated to 175 $\mathrm{cm}$ of body height) and not to body weight. 


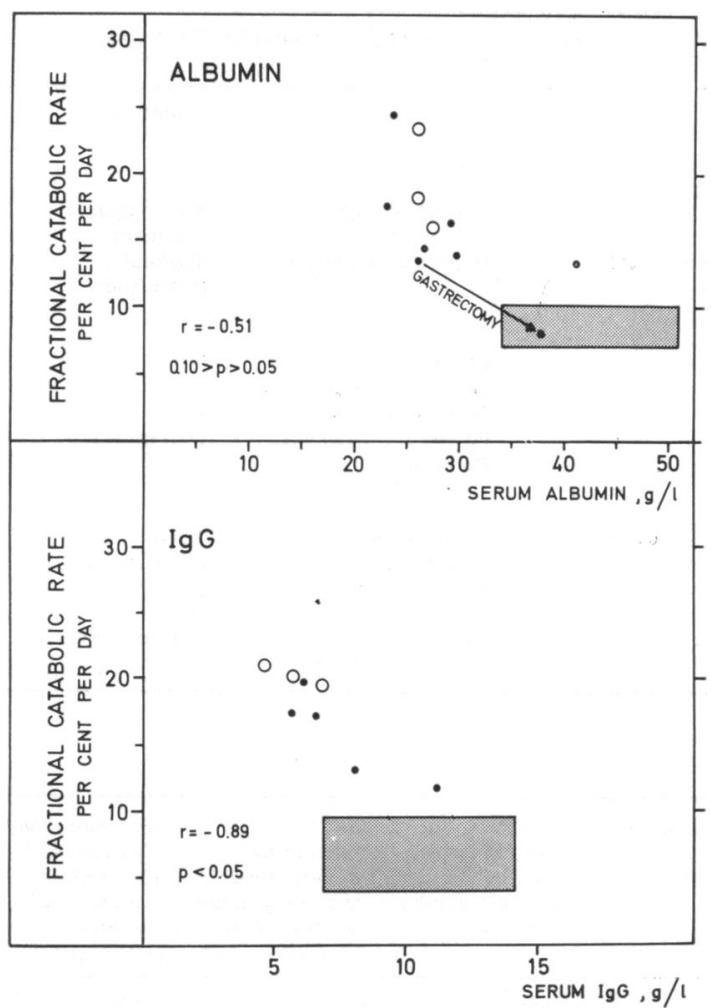

Fig. 1 The inverse relation between serum concentration of albumin and $\mathrm{IgG}$ and their fractional catabolic rates. $\bigcirc=$ Cases 8-9-10 with associated diseases which might influence protein turnover (see text).

$=$ Normal range.

\section{TRANSFERRIN}

In both cases studied the serum concentration was normal and the fractional catabolic rate increased (Table IV).

\section{IG G}

Serum concentration was slightly decreased in six, and normal in two of the eight cases studied (Table V). The fractional catabolic rate was increased in all subjects, and at the same time it was negatively

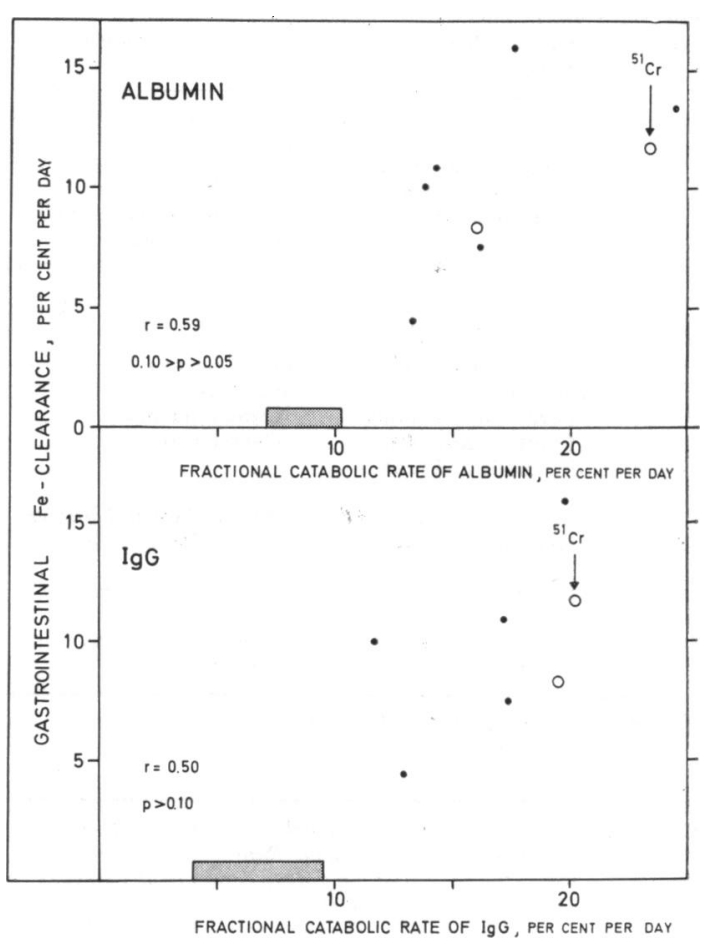

Fig. 2 Fractional catabolic rates of albumin and IgG related to abnormal gastric loss of macromolecules

$\left({ }^{59} \mathrm{Fe}\right.$-iron dextran and, in one instance, ${ }^{51} \mathrm{Cr}$-albumin).

$\bigcirc=$ See Fig. 1

$=$ Normal range.

and significantly $(\mathrm{r}=-0.89, \mathrm{P}<0.01)$ related to serum IgG concentration (Fig. 1). There was no statistically significant correlation between gastrointestinal ${ }^{59} \mathrm{Fe}$ clearance and the $\mathrm{IgG}$ degradation rate (Fig. 2).

IgG synthesis was slightly elevated in five patients and high normal in the remaining three.

IGM TURNOVER

Serum IgM was depressed in two patients (cases 1

\begin{tabular}{|c|c|c|c|c|c|}
\hline Case No. & $\begin{array}{l}\text { Serum Transferrin } \\
(g / l)(1 \cdot 80-2 \cdot 52)\end{array}$ & $\begin{array}{l}\text { Fractional Catabolic } \\
\text { Rate }(\% \text { per day }) \\
(14 \cdot 9-19 \cdot 5)\end{array}$ & $\begin{array}{l}\text { Distribution Ratio } \\
(\%)(45-54)\end{array}$ & $\begin{array}{l}\text { Synthesis Rate } \\
(\mathrm{g} / 175 \mathrm{~cm} / \mathrm{d}) \\
(0 \cdot 80-1 \cdot 79)\end{array}$ & $\begin{array}{l}\text { Faecal Radioiodine } \\
\text { Excretion }(\%)(<0.4)\end{array}$ \\
\hline $\begin{array}{l}7 \\
9\end{array}$ & $\begin{array}{l}1 \cdot 86 \\
2 \cdot 26\end{array}$ & $\begin{array}{l}27 \cdot 9 \\
34 \cdot 0(30 \cdot 8)^{1}\end{array}$ & $\begin{array}{l}63 \cdot 0 \\
53 \cdot 7\end{array}$ & $\begin{array}{l}1 \cdot 32 \\
2 \cdot 39\end{array}$ & $\begin{array}{l}0 \cdot 27 \\
0 \cdot 22\end{array}$ \\
\hline
\end{tabular}

Table IV Transferrin turnover in Ménétrier's disease

${ }^{1}$ Corrected for proteinuria. 


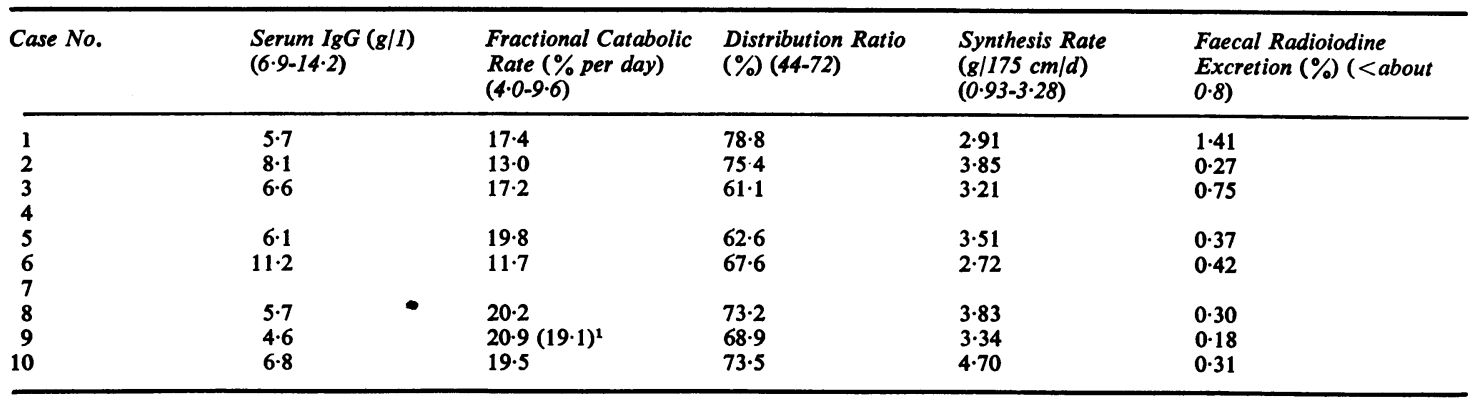

Table V IgG turnover in Ménétrier's disease

${ }^{1}$ Corrected for proteinuria.

\begin{tabular}{llllll}
\hline Case No. & $\begin{array}{l}\text { Serum IgM }(g / 1) \\
(0 \cdot 23-1 \cdot 33)\end{array}$ & $\begin{array}{l}\text { Fractional Catabolic } \\
\text { Rate }(\% \text { per day) } \\
(8-14)\end{array}$ & $\begin{array}{l}\text { Distribution Ratio } \\
\text { Intravascular Mass } \\
\text { as \% of Total Mass } \\
(51-97)\end{array}$ & $\begin{array}{l}\text { Synthesis Rate } \\
(\text { mg/175 cm/day) } \\
(54-563)\end{array}$ & $\begin{array}{l}\text { Faecal Radioiodine } \\
\text { Excretion }(\% \text { of injected } \\
\text { dose in 4-5 days) } \\
(<a b o u t ~ 0.8 \%)\end{array}$ \\
\hline 1 & & 29.4 & 41 & 179 & 1.81 \\
3 & 0.20 & 26.8 & 68 & 182 & 1.01 \\
5 & 0.26 & 31.8 & 87 & 388 & 0.58 \\
6 & 0.40 & 26.7 & 65 & 263 & 0.16 \\
9 & 0.39 & $30.3(24.2)$ & 72 & 543 & 0.72 \\
10 & 0.16 & 29.3 & 70 & & 0.46 \\
\hline
\end{tabular}

Table VI IgM turnover in Ménétrier's disease

${ }^{1}$ Corrected for proteinuria. Normal values are given in parentheses.

and 9, Table VI) and low normal in the remaining cases. The fractional catabolic rate was markedly elevated, from 26.7 to $31.8 \%$ of the intravascular mass per day or almost threefold the normal mean of $11 \%$ per day. The distribution of the protein was normal. On average, $68 \%$ of the total $\mathrm{IgM}$ mass was located intravascularly. IgM synthesis was normal.

\section{PROTEIN INTERRELATIONS}

\section{Catabolic rates}

Patients studied with labelled transferrin or IgG were all studied simultaneously with labelled albumin. From Fig. 3 it appears that the increase in catabolism above the normal mean (percentage of intravascular mass per day) was very similar for all three proteins. The positive correlation between the catabolic rates for IgG and albumin was highly significant $(r=0.73$, $P<0.01$ ).

Comparing the fractional catabolic rates of albumin, IgG, and IgM it was obvious that IgM catabolism was relatively more increased than that of the other two proteins (Fig. 4). The average value of IgM catabolism was $29.1 \%$ of the intravascular mass per day $(264 \%$ of the normal mean), and the corresponding values for albumin and IgG were 16.9 and $17.8 \%$ per day (194 and $262 \%$ of the normal mean), respectively.

\section{Synthetic rates}

Synthetic rates of albumin and IgG seemed to be positively correlated. However, the relationship was not significant. The distribution ratios of albumin, transferrin, and IgG were either high normal or raised in the sense that the fraction of the total mass present in the vascular bed was higher than normal. Some covariation in the distribution ratios of albumin and IgG was observed, but it did not reach a significant level. No correlation existed between the catabolic rate and the distribution ratio of albumin or IgG.

\section{GASTRIC PROTEIN CLEARANCE}

In five patients gastric protein clearance was assessed. However, in two of them (cases 1 and 7) no protein-bound activity was detected in gastric aspirations. In one case (no. 9) the clearance of protein-bound radioactivity was equal to 15 and $19 \%$ of the total metabolic clearance of albumin and IgG, respectively (Table VII).

In patient no. 10, who was the only one with achlorhydria, the gastric clearance of IgG amounted to $47 \%$ of the total metabolic clearance.

Case 8 had a gastric albumin clearance during the augmented histamine test equal to $71 \%$ of the total metabolic clearance (Fig. 5), whereas gastric albumin and IgG clearances after hexamethonium 


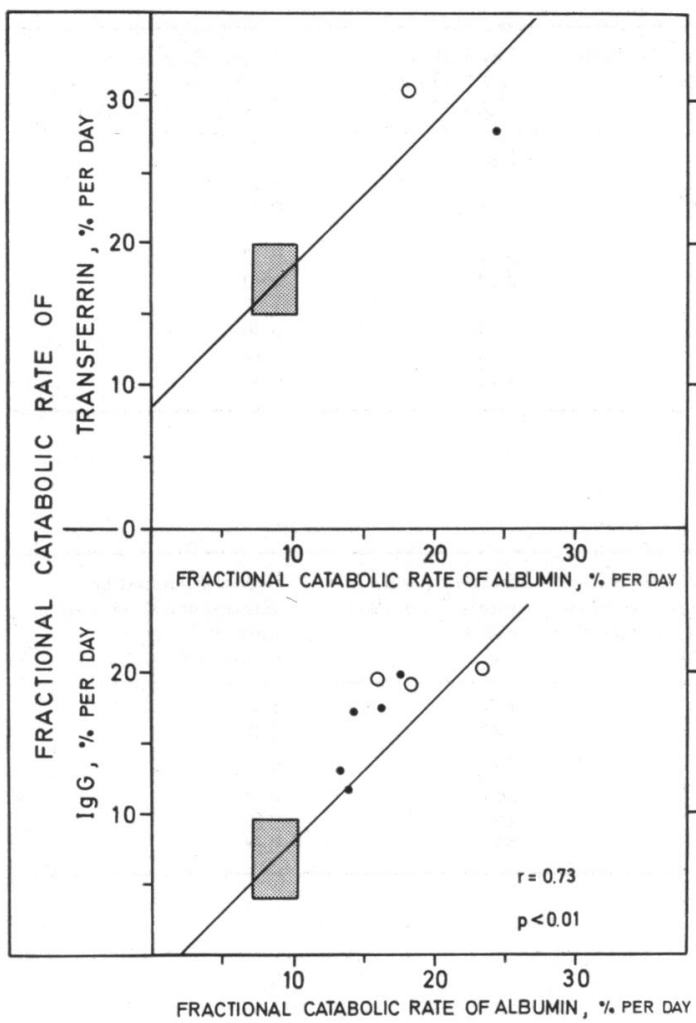

Fig. 3 Albumin catabolism compared with the catabolic rate of transferrin (upper part) and IgG (lower part).

The line $(x=y \pm a)$ has been drawn in such a way that it traverses the normal mean of the catabolic rates of all proteins and predicts the increase in catabolism if a 'bulk loss' occurs, ie, if albumin catabolism is increased $10 \%$ above normal mean, transferrin of IgG catabolism is also increased $10 \%$ above normal mean.

0 Normal range. 


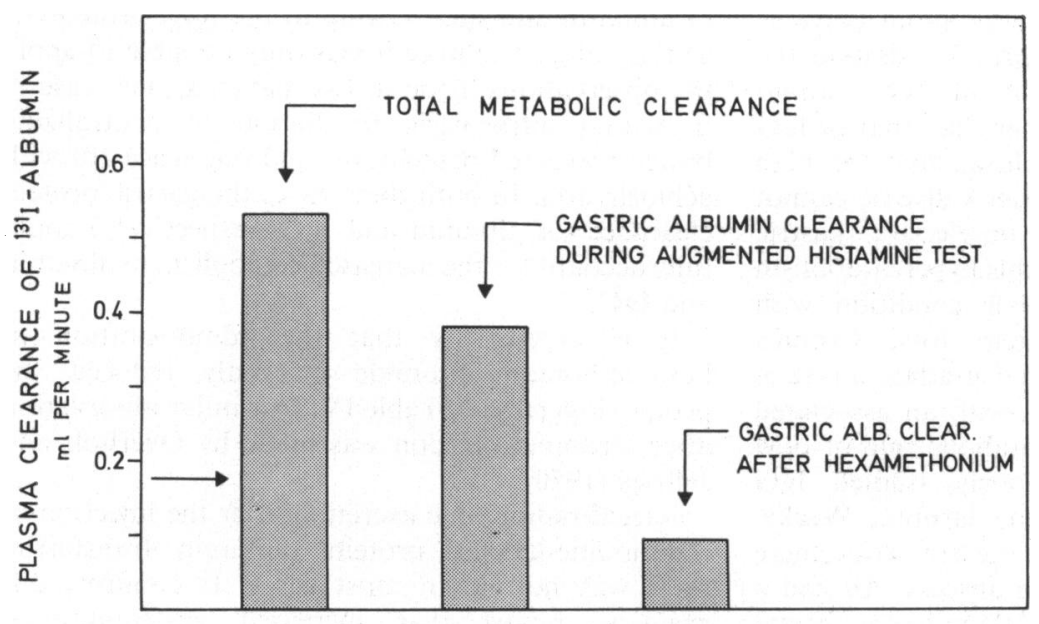

Fig. 5 Total metabolic clearance (ml plasma per minute) and gastric albumin clearance during augmented histamine test and following injection of hexamethonium bromide in Ménétrier's disease (case 8).

For further details see text.

bromide ('medical vagotomy') were only 17 and $21 \%$ respectively, of the total metabolic clearance.

\section{FAECAL RADIOIODINE EXCRET ION}

Faecal excretion of radioiodine from labelled albumin was slightly elevated in four and normal in five cases. In the transferrin studies faecal radioiodine from labelled transferrin was normal. In the IgG studies faecal radioiodine from labelled JgG was normal in seven and raised in only one, in the IgM studies normal in four and elevated in two cases. No correlation was observed between faecal radioiodine excretion and the gastric protein loss estimated from gastrointestinal ${ }^{59} \mathrm{Fe}$ clearance.

\section{Discussion}

The common feature in the 10 cases of Ménétrier's disease studied was the presence of hypertrophic ('giant') rugae of the stomach. None of them presented evidence of a more distal gastrointestinal lesion, and none suffered from malabsorption.

The diagnosis was based on a barium meal and gastroscopy. In two cases (nos. 4 and 8) it was confirmed at laparotomy. In three cases the disease turned out to be transitory, since the symptoms vanished, serum protein rose to normal values, and the radiographic picture of the stomach returned to normal. This rather unusual course of the disease will be described in detail elsewhere.

It is not the intention of the present report to contribute to the definition of 'hypertrophic gastritis' which is still in dispute. Our purpose was to elucidate the mechanism of abnormal protein loss which probably occurs in about $70 \%$ of patients with giant rugae in the stomach (Jarnum, 1963).

In the present report an abnormal protein loss was detected in all patients by means of ${ }^{59} \mathrm{Fe}$-labelled iron dextran, ${ }^{51} \mathrm{Cr}$-albumin, or ${ }^{131} \mathrm{I}-\mathrm{PVP}$. The fractional catabolic rate of albumin was also increased in all, and the increase seemed to be correlated with the gastrointestinal ${ }^{59} \mathrm{Fe}$ clearance although the correlation did not reach a statistically significant level.

Two patients were studied simultaneously with labelled albumin and transferrin and eight patients with labelled albumin and IgG. The increase in fractional catabolic rates of the three proteins above the normal mean was very similar in all cases (Fig. 3). This is strong evidence that the protein loss is a 'bulk loss' which affects a similar fraction of the intravascular masses of these three proteins. The observation is in contrast to the findings in the nephrotic syndrome where a selective protein loss occurs through the glomerular membrane resulting in a higher clearance of relatively low molecular proteins like albumin (molecular weight about 68000 ) than of IgG (molecular weight about 160000 ) (Jarnum, Jensen, and Bro-Jørgensen, 1966).

Six patients were studied with labelled albumin, IgG, and IgM. The relative increase in IgM catabolism was higher (on an average $264 \%$ of the normal mean) than that of albumin and IgG (194 and $262 \%$ of the normal mean, respectively). In absolute terms the average increase of IgM catabolism as a percentage of the intravascular mass per day above the normal mean was 18.1 as opposed to 8.2 and 11.0 for albumin and IgG, respectively. Thus 
the increase in IgM catabolism was about twice as high as that of the other two proteins despite the fact that the molecular weight of IgM (about $920000)$ is six and 13 times higher than that of IgG and albumin, respectively. It follows that the high catabolic rate of IgM in Ménétrier's disease cannot solely be due to abnormal unselective gastric protein loss. The mechanism of this hypercatabolism of IgM is unknown. In another condition with abnormal gastrointestinal protein loss, Crohn's disease, there is also an increased degradation rate of IgM. However, only in patients with an associated abscess did the increase in the catabolic rate of IgM exceed that of the simultaneously studied IgG catabolism (Jensen, Goltermann, Jarnum, Weeke, and Westergaard, 1970). In the present series there was no evidence of an associated abscess. All had a normal temperature and most of them had a normal erythrocyte sedimentation rate and a normal white cell count.

One may speculate whether the stomach is an organ which is normally a major degradation site of IgM. Probably no other organ in the body is exposed to so many antigens (species different proteins) every day. IgM might have an important function in the 'neutralization' of these antigens. In Ménétrier's disease there is a manifold increase in the mucosal surface area, which might mean that the expenditure of IgM is particularly high in this disease. The mucosa is heavily infiltrated with immunocytes (lymphocytes and plasma cells) (Kenney, Dockerty, and Waugh, 1954). Probably, it implicates local antibody synthesis on a large scale. It does not explain the rapid elimination of systemically administered homologous IgM molecules. However, both phenomena may have the same mechanism: a continuous antigen challenge across a much enlarged epithelial membrane with an abnormality high permeability to macromolecules. This would account for the local concentration of immunocytes and for a high 'consumption' of IgM antibodies during local neutralization of antigens. A high local IgM synthesis would result in a high local concentration of IgM as compared to other plasma proteins in the mucosal and submucosal 'pools' of plasma proteins. If so, a large amount of IgM lost in the stomach would be inevitable in the presence of a 'bulk loss' mechanism for protein loss. This mechanism could be further elucidated by means of systemically administered labelled IgM and the determination of specific activity of IgM in gastric juice from patients with Ménétrier's disease. Such studies were not undertaken in the present investigation.

Gastric protein clearance was determined to assess whether the directly observed protein loss in the stomach could account for the increased catabolism of albumin and IgG. Owing to the high proteolytic activity of gastric juice it was only possible to apply the observations made in two patients, one (case 8) in whom intragastric instillation of neutralizing buffer prevented proteolysis, and one (case 10) with achlorhydria. In both these cases the gastric protein clearance (of albumin and IgG, respectively) could fully account for the increased catabolism of albumin and IgG.

It is noteworthy that the administration of hexamethonium bromide markedly reduced the protein loss (case 8, Table IV). A similar observation after atropine injection was made by Overholt and Jeffries (1970).

Faecal radioiodine excretion after the injection of radioiodine-labelled proteins (albumin, transferrin, IgG) was normal in most cases. It confirms our previous report that increased gastrointestinal ${ }^{59} \mathrm{Fe}$ clearance (after injection of ${ }^{59} \mathrm{Fe}$-iron dextran) in the presence of normal faecal radioiodine excretion (after the injection of radiodiodine labelled proteins) permits a topographical diagnosis of abnormal protein loss in the stomach (Westergaard, Jarnum, Jensen, Søltoft, and Yssing 1968).

\section{References}

Berson, S. A., Yalow, R. S., Schreiber, S. S., and Post, J. (1953). Tracer experiments with $\mathrm{I}^{\mathbf{1 3 1}}$-labeled human serum albumin: distribution and degradation studies. J. clin. Invest., 32, 746768.

Citrin, Y., Sterling, K., and Halsted, J. A. (1957). The mechanism of hypoproteinemia associated with giant hypertrophy of the gastric mucosa. New Engl. J. Med., 257, 906-912.

Gordon, R. S., Jr. (1959). Exudative enteropathy: Abnormal permeability of the gastrointestinal tract demonstrated with labelled polyvinylpyrrolidone. Lancet, 1, 325-326.

Jarnum, S. (1963). Protein-losing Gastroenteropathy. Blackwell, Oxford.

Jarnum, S., Jensen, H., and Bro-Jørgensen, K. (1966). Relation between synthesis, catabolism and serum concentration of plasma proteins in various clinical states of hypoproteinaemia. Protides biol. Fluids, 14, 295-300.

Jarnum, S., Westergaard, H., Yssing, M., and Jensen, H. (1968). Quantitation of gastrointestinal protein loss by means of $\mathrm{Fe}^{59}$-labelled iron dextran. Gastroenterology, 55, 229-241.

Jensen, K. B. (1969). Metabolism of human $\gamma$-macroglobulin (IgM) in normal man. Scand. J. clin. Lab. Invest., 24, 205-214.

Jensen, K. B. (1970). Immunoglobulin M (IgM) turnover in hepatitis. Scand J. Gastroent., Suppl. 7, 33-37.

Jensen, H., Bro-Jørgensen, K., Jarnum, S., Olesen, H., and Yssing, M. (1968). Transferrin metabolism in the nephrotic syndrome and in protein-losing gastroenteropathy. Scand. J. clin. Lab. Invest., 21, 293-304.

Jensen, K. B., Goltermann, N., Jarnum, S., Weeke, B., and Westergaard, H. (1970). IgM turnover in Crohn's disease. Gut, 11, 223-228.

Kenney, F. D., Dockerty, M. B., and Waugh, J. M. (1954). Giant hypertrophy of gastric mucosa. Cancer (Philad.), 7, 671-681.

McFarlane, A. S. (1958). Efficient trace-labelling of proteins with iodine. Nature (Lond)., 182, 53.

Mancini, G., Carbonara, A. O., and Heremans, J. F. (1965). Immunochemical quantitation of antigens by single radial immunodiffusion. Immunochemistry, 2, 235-246.

Nosslin, B. (1966). In Applications of tracer theory to protein turnover studies. J. nucl. Biol. Med., 9, 18-19.

Overholt, B. F., and Jeffries, G. H. (1970). Hypertrophic, hypersecretory protein-losing gastropathy. Gastroenterology, 58, 80-87. 
Peterson, E. A., and Sober, H. A. (1960). Chromatography of the plasma protein. In The Plasma Proteins, edited by F. W. Putnam, pp. 105-141. Academic Press, New York and London.

Waldmann, T. A. (1966). Protein-losing enteropathy. Gastroenterology, 50, 422-443.

Waldmann, T. A., Morell, A. G., Wochner, R. D., Strober, W., and
Sternlieb, I. (1967). Measurement of gastrointestinal protein loss using ceruloplasmin labeled with ${ }^{67}$ copper. J. clin. Invest., 46, 10-20.

Westergaard, H., Jarnum, S., Jensen, H., Søltoft, J., and Yssing, M. (1968). Topographic diagnosis of gastrointestinal protein loss. Digestion, 1, 341-352.

\section{The January 1972 Issue}

\section{THE JANUARY 1972 ISSUE CONTAINS THE FOLLOWING PAPERS}

Experimental venous lesions of the colon R. W. MARCUSON, J. O. STEWART, AND ADRIAN MARSTON

Helminthic pseudotumours of the bowel: Thirty-four cases of helminthoma P. P. ANTHONY AND I. W. J. MCADAM

Uniformity of dissecting microscope appearances in proximal small intestine J. A. WALKER-SMITH

Alterations in serum immunoglobulins after resection of ulcerative and granulomatous disease of the intestine IRWIN M. GELERNT, DANIEL H. PRESENT, H. D. JANOWITZ

The relationship between the ingestion of hot coffee and intraoesophageal temperature U. W. DE JONG, N. E. DAY, P. L. MOUNIER-KUHN, AND J. P. HAGUENAUER

Effect of intravenous metoclopramide on gastrooesophageal reflux. J. N. GLANVILLE AND W. D. WALLS

Quantitative variations in the disposition of the enteric surface coat in mouse jejunum. S. N. RAO, T. M. MUKHERJEE, AND WYNN WILLIAMS
Serum gastrin in duodenal ulcer Part III Influence of vagotomy and pylorectomy M. G. KORMAN, J. HANSKY, AND P. R. SCOTT

Local 'Shwartzman equivalent' reaction in active chronic hepatitis MICHAEL J. WHELTON

Kinetics of rifampicin and isoniazid administered alone and in combination to normal subjects and patients with liver disease G. ACOCELLA, L. BONOLLO, M. GARIMOLDI, M. MAINARDI, L. T. TENCONI, AND F. B. NICOLIS

Plasminogen activator in bile during extracorporeal perfusion of pig liver A. JEDRYCHOWSKI, S. P. PARBHOO, AND P. HILLENBRAND

The effect of portacaval anastomosis on oral carbohydrate tolerance and on plasma insulin levels C. D. HOLDSWORTH, LYNNE NYE, AND ELIZABETH KING Anhydrous cholesterol: a new crystalline form in gallstones D. JUNE SUTOR AND P. J. GASTON

Technique A simplified method of cannulating the intestinal lymphatic of the rat ANDREW $L$. WARSHAW

Progress report Treatment of acute alcoholic hepatitis ROBERT H. RESNICK AND FRANK L. IBER

Notes and activities

Copies are still available and may be obtained from the PUBLISHING MANAGER, BRITISH MEDICAL ASSOCIATION, TAVISTOCK SQUARE, LONDON, WC1H 9JR. price $87 \frac{1}{2} \mathrm{p}$ 